\title{
Perilaku Kebersihan Menstruasi pada Siswi SMP di Kota Yogyakarta
}

\author{
Menstrual Hygiene Behavior in Junior High School Students in \\ Yogyakarta City \\ Radita Eka Putri', Enny Fitriahadii, ${ }^{2}$ * \\ ${ }^{1,2}$ Universitas 'Aisyiyah Yogyakarta, Jalan Ring Road Barat No. 63 Mlangi Nogotirto, Gamping, Sleman , \\ Yogyakarta, 55292, Indonesia \\ 2ennyfitriahadi@unisayogya.ac.id* \\ * corresponding author \\ Tanggal Submisi: . 25 Desember 2020, Tanggal Penerimaan: 3 Februari 2021
}

\begin{abstract}
Abstrak
Kebersihan menstruasi merupakan suatu perilaku kegiatan kebersihan dan kesehatan pada saat perempuan mengalami menstruasi. Berdasarkan studi pendahuluan di SMP 2 Muhammadiyah Gamping terdapat 41 siswi yang sudah menstruasi. Jenis penelitian deskriptive menggunakan pendekatan cross sectional. Teknik pengambilan sampel dalam penelitian ini menggunakan total sampling. Hasil penelitian di dapatkan perilaku personal higiene yang baik ditunjukkan dengan frekuensi mandi lebih dari 2 kali, membersihkan kemaluan menggunakan air bersih, membasuh kemaluan dari depan ke belakang, mengganti celana dalam 2 kali sehari, mengeringkan kemaluan menggunakan handuk kering, mengganti pembalut saat penuh dan mengganti pembalut 3 kali sehari, mencuci tangan sebelum dan sesudah mengganti pembalut, mengganti celana dalam bila terkena darah.
\end{abstract}

Kata kunci : perilaku kebersihan menstruasi; siswi SMP

\begin{abstract}
Menstrual hygiene is a hygiene and health activity behavior when women experience menstruation. Based on a preliminary study at SMP 2 Muhammadiyah Gamping, there were 41 students who were menstruating. This type of research is descriptive using a cross sectional approach. The sampling technique in this study using total sampling. The results showed that good personal hygiene behavior was indicated by the frequency of bathing more than 2 times, cleaning the genitals using clean water, washing the genitals from front to back, changing underwear 2 times a day, drying the genitals using a dry towel, changing sanitary napkins when full and changing. sanitary napkins 3 times a day, washing hands before and after changing sanitary napkins, changing underwear when exposed to blood.
\end{abstract}

Keywords: menstrual hygiene behavior; junior high school student

\section{PENDAHULUAN}

Kesehatan reproduksi adalah keadaan sehat yang menyeluruh meliputi aspek fisik, mental, dan sosial dan bukan sekedar tidak adanya penyakit atau gangguan di segala hal yang berkaitan dengan sistem reproduksi, fungsinya proses reproduksi itu sendiri. Salah satu ruang lingkup kesehatan reproduksi adalah kesehatan reproduksi remaja. Data World Health Organization (WHO) (2017) menyebutkan bahwa jumlah remaja di dunia diperkirakan mencapai angka 1,2 milyar atau 18\% dari jumlah penduduk di dunia. Persentase tersebut sebanding dengan persentase jumlah remaja di Indonesia yaitu sebanyak 43,5 juta orang atau sekitar 18\% dari penduduk di Indonesia (WHO, 2017).

Data dari Dinas Kesehatan Yogyakarta tahun 2015 mencatat jumlah remaja di Yogyakarta sebanyak 68,759 atau 16\% dari total penduduk di Yogyakarta. Hal ini dapat 
terlihat bahwa jumlah remaja di dunia, di Indonesia, maupun di Yogyakarta mencapai 18\% jumlah penduduk. Besarnya jumlah remaja perlu mendapat perhatian dalam berbagai aspek seperti aspek kesehatan. Hal ini karena remaja akan memegang peranan di masa yang akan datang sehingga perlu mempersiapkan mereka untuk memasuki tahap kehidupan selanjutnya (Dinkes, 2017).

Usaha untuk menurunkan masalah kesehatan reproduksi adalah dengan menetapkan kesehatan reproduksi remaja sebagai salah satu program pemerintah yang tercantum dalam Peraturan Pemerintah Republik Indonesia Nomor 61 Tahun 2014 Tentang Kesehatan Reproduksi dimana pada pasal 11 ayat 1 poin b yang berbunyi "pelayanan kesehatan reproduksi remaja bertujuan untuk mempersiapkan remaja untuk menjalani kehidupan reproduksi yang sehat dan bertanggung jawab" serta pasal 11 ayat 3 yang berbunyi "pemberian pelayanan kesahatan reproduksi remaja harus disesuaikan dengan masalah dan tahapan tumbuh kembang remaja serta memperhatikan keadilan dan kesetaraan gender, mempertimbangkan moral, nilai agama, perkembangan mental, dan berdasarkan ketentuan peraturan perundang-undangan" (Irianto, 2015). BKKBN (2012) juga mengadakan program kesehatan reproduksi pada remaja yaitu dengan mengadakan Pelayanan Kesehatan Peduli Remaja (PKPR) yang diampu Dinas Kesehatan tingkat Kabupaten atau Kota, dikoordinasi Dinas Kesehatan tingkat Provinsi, untuk melayani kesehatan remaja dan dijalankan oleh Puskesmas.

Menurut Penelitian Verawati (2018) dengan Judul Hubungan Penggunaan Panty Liner Dengan Kejadian Keputihan Pada Mahasiswa Kebidanan Semester Empat di Universitas 'Aisyiyah Yogyakarta didapatkan hasil bahwa ada hubungan antara penggunaan panty liner dengan kejadian keputihan pada mahasiswa kebidanan semester empat di Universitas 'Aisyiyah Yogyakarta artinya kebersihan daerah genetalia sangat penting untuk mencegah terjadinya penyakit atau ketidak nyaman pada daerah genetalia wanita. Penelitian lain menyebutkan bahwa perilaku membersihkan daerah genatalia akan berdampak pada penurunan nyeri menstruasi (Sabarudin, HS, 2017).

Kebaruan dari penelitian ini adalah sepengetahuan peneliti bahwa perilaku pada masa anak SMP terkait personal hygiene pada daerah genetalia masih belum banyak yang memperhatikannya sehingga peneliti perlu meneliti dengan tema kebersihan menstruasi pada siswi SMP. Urgensi dari penelitian ini adalah mencegah sedini mungkin komplikasi atau ketidaknyamanan pada masa menstruasi. Berdasarkan hasil studi pendahuluan yang dilakukan di SMP 2 Muhammadiyah Gamping terdapat 41 siswi kelas VII. Pada saat pengambilan data awal, dilakukan wawancara singkat terhadap beberapa siswi dan dari hasil wawancara yang sudah dilakukan, 4 dari 10 siswi didapat pengetahuan tentang personal hygine terhadap kesehatan reproduksi masih sangat kurang dan ditemukan beberapa siswi yang mengalami keputihan. Tujuan dari penelitian ini adalah untuk mengetahui perilaku kebersihan menstruasi pada siswi SMP.

\section{METODE PENELITIAN}

Jenis penelitian ini menggunakan desain penelitian deskriptive dan menggunakan pendekatan cross sectional, yaitu suatu rancangan penelitan dengan melakukan pengukuran atau pengumpulan. Teknik pengambilan sampel menggunakan total sampling. Instrumen pada penelitian ini menggunakan master table dan kuisioner. Data yang diambil adalah data sekunder dan data primer. Sebelum pengambilan data penelitian peneliti melakukan ijin penelitian dan etical clearence. 


\section{HASIL DAN PEMBAHASAN}

\begin{tabular}{|c|c|c|c|}
\hline \multicolumn{4}{|c|}{ Tabel 1. Data Hasil Penelitian } \\
\hline & Usia & Frekuensi (n) & Persentase $(\%)$ \\
\hline & 12 & 3 & 7,3 \\
\hline & 13 & 16 & 39,0 \\
\hline & 14 & 12 & 29,3 \\
\hline & 15 & 8 & 19,5 \\
\hline & 16 & 1 & 2,4 \\
\hline & 17 & 1 & 2,4 \\
\hline \multicolumn{4}{|c|}{ a. Pengetahuan } \\
\hline Kurang & & 8 & 19,5 \\
\hline Cukup & & 25 & 61,0 \\
\hline Baik & & 8 & 19,5 \\
\hline \multicolumn{4}{|c|}{ b. Sikap } \\
\hline Kurang & & 41 & 100,0 \\
\hline Cukup & & 0 & 0 \\
\hline Baik & & 0 & 0 \\
\hline \multicolumn{4}{|c|}{ c. Perilaku } \\
\hline Kurang & & 3 & 7,3 \\
\hline Cukup & & 23 & 56,1 \\
\hline Baik & & 15 & 36,6 \\
\hline Total & & 41 & 100,0 \\
\hline
\end{tabular}

a. Karakteristik Responden

Rata-rata usia remaja putri pada penelitian ini 12-17 tahun. Dengan usia termuda 12 tahun dan usia tertua 17 tahun. Berdasarkan tabel 4.1 menunjukan bahwa sebagian besar remaja putri dalam penelitian ini usia 12 tahun yaitu 3 orang $(7,3 \%)$ dan yang paling sedikit adalah usia 16 dan 17 tahun yaitu masing-masing 1 orang $(2,4 \%)$. Hal ini dapat disimpulkan bahwa pada usia 12-17 tahun responden sudah mengalami menstruasi.

b. Pengetahuan Responden

Dari tabel 1 pengetahuan menunjukkan bahwa dari 41 responden (100\%) ada beberapa responden yang masih kurang mendapatkan pengetahuan tentang kebersihan menstruasi yaitu sebanyak 8 orang $(19,5 \%)$, cukup 25 orang $(61,0 \%)$, dan baik 8 orang $(19,5 \%)$.

c. Sikap Responden

Pada variable sikap menunjukan bahwa dari 41 responden sikap saat menjaga kebersihan menstruasi masih semua kurang. Dan pada tabel perilaku menunjukan bahwa semua responden penelitian yaitu remaja putri tindakan melakukan VH (Vulva Hygiene) dengan status kurang 3 orang $(7,3 \%)$, cukup 23 orang $(56,1 \%)$, dan status baik 15 orang $(36,6 \%)$.

d. Perilaku Responden

Berdasarkan dari tabel 1 perilaku responden menunjukkan bahwa 41 siswi terdapat 23 siswi $(56,1 \%)$ berstatus cukup dalam berperilaku menjaga kebersihan daerah kewanitaan saat menstruasi. 


\section{PEMBAHASAN}

Gambaran karakteristik siswi di SMP 2 Muhammadiyah Gamping Yogyakarta adalah rata-rata usia remaja putri pada penelitian ini 12-17 tahun dengan usia termuda 12 tahun dan usia tertua 17 tahun. Berdasarkan tabel 1 menunjukkan bahwa sebagian besar remaja putri dalam penelitian ini usia 12 tahun yaitu 3 orang $(7,3 \%)$ dan yang paling sedikit adalah usia 16 dan 17 tahun yaitu masing-masing 1 orang $(2,4 \%)$. Hal ini dapat disimpulkan bahwa pada usia 12-17 tahun responden sudah mengalami menstruasi.

Usia tersebut berada dalam rentang usia 10-19 tahun, dimana masa remaja ini merupakan periode pematangan organ reproduksi manusia. Adapun usia remaja ini berada dalam rentang usia 10-12 tahun yang merupakan masa remaja awal dan masa pubertas yang ditandai dengan perubahan fisik yang salah satu cirinya adalah terjadinya menarche atau menstruasi pertama pada remaja putri (Pinem, 2011). Soetjiningsih (2010) menjelaskan bahwa rata-rata usia menarche adalah usia 10,5-15,5 tahun. Hasil Riset Kesehatan Dasar (2010), menjelaskan bahwa menarche terjadi atara usia 9-20 tahun.

Dari tabel 1 pengetahuan diatas menunjukkan bahwa dari 41 responden (100\%) ada beberapa responden yang masih kurang mendapatkan pengetahuan tentang kebersihan menstruasi yaitu sebanyak 8 orang $(19,5 \%)$, cukup 25 orang $(61,0 \%)$ dan baik 8 orang $(19,5 \%)$. Dalam penelitian ini, pengetahuan yang dimiliki responden sudah cukup bagus. Mayoritas responden sudah mengetahui apa itu yang dimaksud dengan personal hygine. Dalam perilaku kebersihan menstruasi sangatlah penting mengetahui bagaimana cara-cara membersihkan organ reproduksi dengan tepat.

Berdasarkan hasil penelitian didapatkan bahwa sebagian besar remaja mempunyai perilaku cukup yaitu sebanyak $23(56,1 \%)$ dan memiliki pendidikan yang sama. Responden memiliki perilaku cukup menjaga kebersihan diri dengan berusaha menjaga kebersihan dengan selalu membersihkan alat kelamin menggunakan sabun dan air bersih. Dari segi biologis, manajemen atau bisa disebut dengan perilaku keseharian seseorang merupakan suatu kegiatan yang bersangkutan baik yang dapat diamati atau tidak dari pihak luar (Notoatmodio, 2010). Sebagaimana Lawan, Yusuf \& Musa (2010) menyatakan bahwa perilaku hygine menstruasi merupakan aktivitas untuk mempertahankan kesehatan seksual dan mencegah terjadinya penyakit seksual.

Gambaran perilaku kebersihan menstruasi dalam penelitian ini adalah perilaku hygine menstruasi dengan mengobservasi secara tidak langsung yaitu dengan melakukan pendekatan recall atau wawancara kepada reponden. Responden diminta mengingat kembali perilaku yang telah dilakukan beberapa waktu lalu (Maulana, 2010).

Perilaku membersihkan alat kelamin dengan air bersih sudah seluruh responden 41 responden (100\%) membersihkan alat kelamin menggunakan air bersih. Thakre (2011) dalam penelitiannya di India menyebutkan bahwa hanya sebagian besar dari respondennya yaitu $58,8 \%$ membersihkan dengan sabun dan yang paling sedikit sekitar $29 \%$ membersihkannya dengan air dan antiseptik. Menurut Permenkes RI nomor 32 tahun 2017 Standar Baku Mutu Kesehatan Lingkungan untuk Media Air untuk Keperluan Higiene atau standar bisa dikatakan air itu bersih meliputi air dalam keadaan terlindung dari sumber pencemaran, binatang pembawa penyakit, dan tempat perkembangbiakan, Aman dari kemungkinan kontaminasi. Menurut Army (2010) bila kencing di toilet umum sebaiknya gunakan air kran atau shower. Jangan menggunakan air yang ditampung di bak atau ember. Air tersebut bisa saja sudah tergenang dalam waktu lama, atau mungkin saja sudah kotor. Memilih toilet jongkok, daripada toilet duduk. Toilet jongkok tidak menyentuh langsung permukaan toilet dan lebih hygenis. Jika terpaksa menggunakan toilet duduk, bersihkan dulu pinggiran toilet dengan tisu.

Perilaku responden lainnya yaitu membersihkan kemaluan menggunakan sabun. Dalam penelitian ini sudah sebagian besar membersihkan kemaluan menggunakan sabun. Saat menstruasi maupun hari-hari biasa, seharusnya individu membersihkan vagina dengan 
air bersih dan lebih baik lagi dengan air hangat tanpa menggunakan sabun khusus pembersih vagina atau pewangi vagina karena pada vagina terdapat kuman yang berfungsi memproduksi asam yang dapat mencegah bakteri masuk ke dalam vagina dan menyebabkan infeksi.

Cara melakukan Vulva higiene yang benar sebagian besar siswi (responden) sudah mengetahui cara yang benar yakni membasuh yang benar dari depan ke belakang. Setelah melakukan VH dengan benar setelah itu mengeringkan kemaluan. Sebagian besar responden mengeringkan kemaluan menggunakan handuk bersih dan kering. Membersihkan vagina dengan benar itu sangat penting bagi kebersihan alat kelamin kita. Hal ini dilakukan supaya vagina tidak lembab dan mencegah bakteri jahat tumbuh di daerah kemaluan (Pudiastuti, 2012). Menurut Army (2010) cebok yang salah dapat mengakibatkan berbagai gangguan pada organ kewanitaan. Karena ketidaktahuannya banyak perempuan cebok dari belakang ke depan. Padahal cara itu sama saja menarik kotoran ke daerah vagina. Cara cebok yang benar adalah dari depan ke belakang agar tidak menjadi lahan subur bagi kuman dan bakteri. Kuman yang terdapat dalam vagina dapat mengakibatkan berbagai keluhan seperti keputihan, bahkan lebih parah lagi jika bakteri tersebut menyerang saluran kemih atau saluran kencing perempuan yang menyebabkan penyakit infeksi saluran kemih.

Perilaku selanjutnya penggunaan celana dalam, dari penelitian yang sudah dilakukan responden sebagian besar sudah mengganti celana dalam 2 kali sehari dan bila celana dalam terkena darah, seluruh responden langsung mengganti celana dalam. Dengan mengganti celana dalam secara rutin minimal 2 kali sehari atau segera ketika celana dalam terkena darah dapat mencegah vagina dari kelembapan yang berlebihan. Selain itu, infeksi juga sering terjadi akibat celana dalam yang tidak bersih (Kusmiran, 2012).

Perilaku mengganti pembalut saat menstruasi dari penelitian yang sudah dilakukan di dapatkan data dari 41 responden sudah sebagian besar mengganti pembalut lebih dari 2 kali dalam sehari. Penggantian pembalut tidak boleh lebih dari 6 jam, karena pembalut akan menyimpan bakteri ketika lama tidak diganti. Ketika individu merasa tidak nyaman akibat vaginanya lembab, maka diharuskan segera mengganti pembalut. Karena ketika vagina lembab, mikroorganisme dan jamur akan berkembangbiak sehingga dapat mengganggu ekosistem vagina yang mengakibatkan vagina menjadi gatal dan berbau (Kusmiran, 2012). Dari seluruh responden sebagian besar responden sudah mengganti pembalut bila sudah penuh. Untuk penggantian pembalut saat menstruasi bila darah masih banyak diharuskan ganti pembalut minimal 3 kali sehari (Kusmiran, 2012).

Hal ini karena jika terlalu lama tidak diganti, menyebabkan pembalut jadi sangat kotor oleh darah dan ini bisa menjadi tempat bersarangnya banyak bakteri dan jamur. Sehingga, jika tidak secara berkala diganti, bakteri akan berkembang dan membuat daerah kewanitaan bermasalah (Rachmad, 2016). Penelitian Suryati (2012) pada remaja putri SMPN 2 Depok bahwa dari 186 responden, sebesar 143 orang $(76,9 \%)$ mempunyai perilaku kebersihan saat menstruasi baik, dimana perilaku baik ditunjang oleh frekuensi mengganti pembalut pada saat menstruasi sedikit sebesar $47.8 \%$. Frekuensi mengganti pembalut saat menstruasi sedikit $68,3 \%$, dan hal - hal yang perlu - diperhatikan saat menstruasi sebesar 96,8\% dan mengetahui akibat yang ditimbulkan jika lidak menjaga kebersihan saat menstruasi sebesar $79 \%$. Thakre (2011) menjelaskan bahwa praktik higiene menstruasi yang baik ditunjukkan dengan penggunaaan pembalut dan mencuci alat kelamin secara adekuat.

Perilaku lainnya ketika siswi menggunakan pembalut kain dari penelitian ini diperoleh sebanyak 41 responden (100\%) tidak menggunakan pembalut kain. Menggunakan pembalut kain dikhawatirkan pembalut kain tersebut kurang higiene akibat perawatannya yang kurang baik, seperti cara mengeringkan ditempat tersembunyi dan tidak terkena sinar matahari yang berisiko tumbuhnya mikroba atau larva yang dapat menyebabkan vagina berbau tidak sedap atau terjadi keputihan (Ali, 2010). Penelitian ini sesuai dengan penelitian Lawan, Yusuf \& Musa (2010) menyatakan bahwa $93.8 \%$ respondennya menggunakan pembalut selama 
menstruasi, dan terdapat $62 \%$ yang menggunakan kain yang dicuci/direbus dikeringkan, dan dipakai ulang, atau menggunakan sepotong kain yang dibuang setelah dipakai. Perilaku merebus dan mengeringkan kain sebelum dipakar ulang merupakan perilaku perlindungan terhadap infeksi. Selain itu, perilaku mencuci tangan sebelum dan sesudah mengganti pembalut seluruh responden sudah melakukannya (100\%). Seluruh responden juga mencuci pembalut bekas pakai sebelum dibuang dan membungkus pembalut bekas pakai sebelum dibuang.

\section{SIMPULAN}

Berdasarkan hasil penelitian yang dilakukan dan data yang diperoleh di SMP 2 Muhammadiyah Gamping dapat diambil kesimpulan pada remaja putri kelas 7 memiliki ratarata usia 13 tahun, dengan usia termuda 12 tahun dan tertua 17 tahun dan rata-rata usia menarche adalah 10 tahun, dengan usia termuda 12 tahun dan usia tertua 17 tahun. Perilaku higiene yang baik ditunjukan dengan frekuensi mandi lebih dari 2 kali, membersihkan kemaluan menggunakan air bersih, membasuh kemaluan dari depan ke belakang, mengganti celana dalam 2 kali sehari, mengeringkan kemaluan mengguanakan handuk kering dan tissu, mengganti pembalut saat sudah penuh dan mengganti pembalut 3 kali sehari, mencuci tangan sebelum dan sesudah mengganti pembalut, mengganti celana dalam bila terkena darah, membuang pembalut menggunakan plastik. Sedangkan perilaku higiene yang kurang baik tidak mengganti pembalut 3 kali sehari bila darah yang keluar masih banyak, menggunakan celana dalam yang tidak menyerap keringat, tidak mengganti pembalut saat darah sudah berkurang dalam sehari.

\section{SARAN}

Hasil penelitian ini dapat dijadikan bahan tambahan bacaan dalam meningkatkan pengetahuan peserta didik atau dijadikan sebagai salah satu referensi dan acuan dalam menetapkan latar belakang dalam melakukan pendidikan kesehatan mengenai masalah higiene saat menstruasi dan pentingnya menjaga higiene menstruasi sejak dini.

\section{REFERENCE}

Anurogo, D. (2011). Psikologi Kebidanan Analisis Perilaku Wanita Untuk Kesehatan. Jakarta: Salemba.

Arikunto, S. (2012). Metodologi Penelitian kesehatan. Jakarta: Rineka Cipta.

Berham, Kliegnam \& Arvin. (2010). Ilmu Kesehatan Anak Nelson Edisi 15 Vol 3. No. 03. Jakarta: EGC.

Depkes, RI. (2010). Kesehatan Reproduksi. UNFPA. Jakarta.

Dekes, RI. (2012). Profil Kesehatan Indonesia. Jakarta: Depkes RI.

Fitryah. (2014). Gambaran Perilaku Higiene Menstruasi Para Remaja Putri di Sekolah Dasar Negri di wilayah kerja Puskesmas Pisangan. Skripsi S1 Fakultas Ilmu Keperawatan, Fakultas Kedokteran dan Ilmu Kesehatan, Universitas Islam Syarif Hidayatullah Jakarta. Jurnal Ilmiah Kesehatan Keperawatan. Vol. 7 No. 3, pp: 11-12.

Irianto, S. (2015). Kesehatan Reproduksi dan Kontrasepsi. Jakarta: Trans Info Media.

Kemenkes. (2014). Survei Demografi dan Kesehatan Indonesia 2012 Kesehatan

Kusmiran. (2014). Kesehatan Reproduksi Remaja dan Wanita. Jakarta: Salemba Medika.

Manuaba, I. (2010). Ilmu Kebidanan, Penyakit Kandungan \& Keluarga Berencana Untuk Pendidikan Bidan. Jakarta: EGC.

Musrifatul dan A. Azis Alimul Hidayat. (2008). Keterampilan Dasar Praktik Klinik Untuk Kebidanan. Jakarta: Salemba Medika.

Notoatmojo, S. (2014). Metodologi Penelitian Kesehatan. Jakarta: Rineka Cipta. 
Peraturan Menteri Kesehatan RI. (2007). Nomor: 369/MENKES/SK/III/2007.Tentang standar profesi bidan.

Pudjiastuti, S. (2010). Kebersihan Diri. Yakarta: EGC.

Sevita. (2015). Gambaran Perilaku Higiene Menstruasi pada Siswi Sekolah Dasar di Kecamatan Jetis, Yogyakarta. Jurnal Ilmiah Kesehatan Keperawatan. Vol. 7 No. 2, pp: 9-12.

Sarwono. (2011). Psikologi Remaja. Jakarta: PT Rajagrafido Persada.

Sabarudin, Hs Dkk. (2017). Hubungan Pengetahuan Tentang Dysmenorhea Dengan Perilaku Penanganan Dysmenorhea Di Pesantren As-Syalafiah Mlangi Yogyakarta. Skripsi. http://digilib2.unisayogya.ac.id/handle/123456789/1775

Sulistyo. (2014). Metode Penelitian Pendidikan Pendekatan Kuantitatif, kualitatif dan R\&D. Bandung: Alfabeta.

Suryati, B. (2012). Perilaku kebersihan remaja saat menstruasi. Jurnal Health Quality. Vol. 3 No. 1, Nop 2012. pp: $54 \quad-\quad 65$ http://stikesbpi.ac.id/media/file/897084724Jurnal_Perilaku_Kebersihan_Remaja_Saat_ Mestruasi.pdf diakses pada tanggal 7 Januari 2018.

Varney, H. (2010). Buku Ajar Asuahn Kebidanan Volume 2. Jakarta: EGC.

Verawati, SU dkk (2018). Judul Hubungan Penggunaan Panty Liner Dengan Kejadian Keputihan Pada Mahasiswa Kebidanan Semester Empat Di Universitas 'Aisyiyah Yogyakarta. Skripsi. http://digilib2.unisayogya.ac.id/handle/123456789/1259

Wong, L. (2010). Buku Ajar Keperawatan Pediatrik. Jakarta: EGC.

World Health Organization, 2014. Seksual Bebas pada Remaja. https://www.google.com/searchpdf seksual bebas pada remaja menurut WHO. Diakses pada 24 November 2017.

World Health Organization, 2017. Seksual Bebas pada Remaja. https://www.google.com/searchpdf seksual bebas pada remaja menurut WHO. 